\title{
A new take-off for EUWIN!
}

\author{
Steven Dhondt \\ Peter Totterdill \\ Geert Van Hootegem
}

The European Workplace Innovation Network (EUWIN) was created in 2013 at the request of the European Commission (DG GROW). Its goal was to develop and promote the idea of Workplace Innovation at the European level. The European Commission wanted to spread the idea that innovation in companies not only was the result of R\&D investments but needed to be supported by the work practices in companies too! A substantial amount of the innovative ideas originates in the minds of firstline workers. And equally important, more than half of innovations do not succeed because employees have not been engaged in the innovation process itself. The European Commission sees this as an enormous opportunity to boost the innovative potential of Europe. EUWIN was born!

Over the past years, the network developed itself speedily and with ever greater impact. In the end, EUWIN had reached over 10.000 persons and companies through conferences. Hundreds of thousands of persons looked for information on the knowledge bank and websites created with the help of Workplace Innovation Ltd. Hundreds of experts and collaborators pushed the message across to thousands of companies all over Europe. Even the European Commission was astonished by the network-effect the EUWIN-initiative created. The positive impact secured that the European initiative received more funding than planned. And even after the finalization of the European funding for EUWIN, the European Commission submitted a call at the beginning of 2019 for five new workplace innovation networks. Nineteen proposals were submitted. Workplace Innovation has found some hard ground all over Europe.

For us as coordinators of the EUWIN-network, we remain contacted by so many persons from all over Europe. With the partnership that originally supported EUWIN, we had made an agreement not to be too formally about all the activities. EUWIN would function as a loosely coupled network to support any action at the EU-level on the topic of workplace innovation. This has worked fine in the past years since the final funding from the EU. In 2018, together with University of Agder, the network organized a major event in Norway. Workplace Innovation Europe (WIE) continued to help Scotland develop its workplace innovation strategy with the active involvement of EUWIN partners. In the Basque Country, Sinnergiak is fully developing the Gipuzkoa Workplace Innovation Platform. In Belgium, Flanders Synergy transformed itself into Workitects. And so on. Gradually, it became clear to the core partnership that EUWIN needs a more formal grounding. The network partners are getting more and more questions about coordinating European initiatives, about training and accreditation of workplace innovation specialists, about how to fund and support company workplace innovation initiatives, how to develop national and regional programmes to support workplace innovation. 
It is great that workplace innovation receives so much attention all over Europe. And this is why we, as the core partnership of EUWIN, see the responsibility to give EUWIN a new take-off. This time not funded by the European Commission, but rather as a collaborative effort from the network partners. In the past months, the network has developed a proposal how to collaborate, what topics to collaborate on and how to fund these initiatives. Bottom-line: EUWIN is relaunching itself to promote and develop workplace innovation. The focus is on European initiatives. The partners look after the national and regional interests. EUWIN will come with more conferences, website and knowledge bank initiatives, with more ideas about accreditation of specialists, with more news and many more ideas. And this is where you yourself come in! EUWIN is not possible without the help of so many individuals and organisations. It is you who needs to provide us with ideas and suggestions. Our emails are available. Please let us know what you think!

Steven Dhondt, Peter Totterdill \& Geert Van Hootegem 